CRÍtICA

\title{
PRESERVAÇÃO E DESENVOLVIMENTO
}

\author{
TERRAS INDÍGENAS E UNIDADES DE CONSERVAÇÃO \\ DA NATUREZA - $O$ DESAFIO DAS SOBREPOSIÇÕES \\ Fany Ricardo (org.). São Paulo: Instituto Socioambiental, 2004. (687 págs)
}

Ana BeAtriz Miraglia e Rui SÉrgio Murrieta

[1] O "Relatório Brundtland" foi encomendado pela assembléia geral da ONU em 1983 e publicado em 1987.

[2] O conceito "etnodesenvolvimento", formulado pelo antropólogo mexicano Rodolfo Stavenhagem, surgiu após a Reunión de Expertos sobre Etnodesarrollo y Etnocídio em América Latina, organizada pela UNESCO em 1981, em San José de Costa Rica.
Os custos ambientais gerados pelo desenvolvimento industrial das sociedades humanas têm sido uma preocupação desde o século XIX. Contudo, foi a partir da década de 1980, sob a égide do desenvolvimento exponencial da revolução tecnológica e seus efeitos desastrosos na biosfera, que os países centrais e agências multilaterais foram forçados a refletir sobre a formulação de uma racionalidade alternativa ao industrialismo. O termo "desenvolvimento sustentável" é produto desse debate e se popularizou no final da década de oitenta com a publicação do Relatório Brundtland ${ }^{1}$. Paralelamente, no mesmo período, a noção "etnodesenvolvimento" apareceu com a função primordial de sublinhar a necessidade de respeitar em conjunto com as considerações ambientais - a diversidade sociocultural ${ }^{2}$. São esforços que vêm tentando articular em um único paradigma preocupações tanto ambientais e conservacionistas quanto sociais e políticas, sem abrir mão da perspectiva de desenvolvimento econômico.

No entanto, historicamente, nos debates ambientais as diferentes posturas éticas acerca da convivência entre conservação ambiental e sociedades humanas não caminham em direção a soluções integradas. Em outros termos, o debate tem sido tenso quando atitudes éticas ambientais levam a posicionamentos extremos, principalmente no que se refere aos modos de equacionar as variáveis socioambiental, cultural e econômica. Assim, estabeleceu-se a oposição representada por um lado pela ênfase nos usos humanos do meio ambiente como fonte inesgotável de recursos e por outro pela manutenção da integridade ambiental dos ecossistemas sem ponderação de custos socioculturais envolvidos. Nesse embate, foi o segundo posicionamento, que defende a criação de áreas protegidas com exclusão de populações humanas, que se consolidou no mundo ocidental como o principal instrumento de conservação da biodiversidade. Apenas recentemente a possibilidade de integração de grupos humanos na gestão ambiental de áreas protegidas começou a ser considerada e operacionalizada. 
Com o intuito de registrar e refletir sobre os desdobramentos conflituosos dessa história, o livro Terras Indígenas e Unidades de Conservação da natureza, editado pelas antropólogas Fany Ricardo e Valéria Macedo, reúne trabalhos, entrevistas e depoimentos de acadêmicos, juristas, ativistas, indigenistas e indígenas que estudam e vivem impasses desse enredo. O tema central é a sobreposição entre Terras Indígenas (TIs)e Unidades de Conservação (UCs). Em outras palavras, a problemática que traz as TIs para o centro da discussão sobre políticas de preservação da biodiversidade no Brasil.

Representando 12,5\% do território nacional, as Terras Indígenas, a maior parte localizada na Amazônia Legal (20,96\% da área da região), são territórios habitados e manejados por comunidades humanas nativas que concentram áreas de floresta com altos níveis de biodiversidade. Essas áreas apresentam maior integridade ecológica do que seus entornos (consideração especialmente válida para TIs amazônicas), o que as torna relevantes não apenas da perspectiva sociocultural, mas também ambiental. Esse argumento é uma constante na publicação, o que leva à tese de que a não inclusão das TIs na legislação ambiental em vigor - o Sistema Nacional de Unidades de Conservação (SNUC) seria um dos grandes equívocos da política ambiental oficial.

O livro promove uma discussão rica acerca da temática das sobreposições reunindo abordagens que tratam das diversas dimensões do assunto. Na primeira parte, são analisados os aspectos históricos, antropológicos, jurídicos, econômicos, políticos e ecológicos gerais da questão das sobreposições. Por meio da reunião de reflexões de atores de diferentes contextos institucionais, sociais e culturais, a proposta é que seja feito um exercício de "compreensão das razões do outro", nas palavras das editoras. Assim, pretende-se transformar diferenças antagônicas relativas à problemática da sobreposição "em formas de intercâmbio, negociação, aprendizagem, tolerância, acordo". Na segunda parte, os capítulos tratam de casos significativos de sobreposição entre TIs e UCs existentes no Brasil e seguem a mesma proposta - promover o debate a partir da captura da pluralidade de pontos de vista sobre o tema.

Não há dúvida de que a publicação reúne um conjunto valioso e único de informações sistematizadas para consulta e reflexão sobre TIs e UCs, bem como uma importante contribuição para profissionais e estudiosos envolvidos com problemáticas socioambientais e povos indígenas do Brasil. Entretanto, ao privilegiar o mapeamento dos posicionamentos variados sobre o tema das sobreposições, o livro acaba não se aprofundando em algumas questões teóricas centrais à problemática abordada. Nesse sentido, contribuiria para o debate a inclusão de análises mais verticalizadas sobre os conceitos de "sustentabilidade" e "desenvolvimento sustentável" e sua aplicação no que se refere à presença humana em Unidades de Conservação, no caso específico, à fixação local de populações indígenas. Especialmente análises feitas a partir 
da perspectiva da Geografia, da Biologia de Conservação ou da Ecologia Humana que tratassem dos desafios empíricos à operacionalidade destas noções.

Esses conceitos são abordados brevemente em artigos da primeira parte da publicação. Mas a discussão a respeito não vai além das definições semânticas mais genéricas, sem que se definam diretrizes operacionais concretas ou se superem definitivamente essas matrizes conceituais já extensivamente discutidas na literatura. Entre os problemas mais básicos da construção de modelos viáveis e críveis está a falta de uma prática sólida de interdisciplinaridade, principalmente na interface entre ciências naturais e sociais, questão apontada por vários autores do livro. O maior problema para a realização de tal interface é a ausência de formação prévia adequada nos programas de graduação e pós-graduação do Brasil. O engessamento burocrático e o corporativismo institucional e intelectual das universidades nacionais têm tornado impossível a formação de profissionais capazes de atuar no campo do desenvolvimento diante das novas demandas de formação acadêmica múltipla. Este problema é ainda mais óbvio quando se leva em consideração a longa tradição interdisciplinar de várias escolas de pensamento no exterior, que na sua maioria foram ignoradas tanto pelos cientistas sociais quanto pelos cientistas naturais brasileiros. Essa negligência (voluntária ou não) reflete-se na troca ínfima de informação estabelecida entre as iniciativas brasileiras e as de outros países, principalmente da Ásia e África.

Impasse que nos traz de volta, por exemplo, para o debate sobre a proposta do Instituto Socioambiental de uma categoria de manejo específica para aplicação em Terras Indígenas, as RIRN (Reserva Indígena de Recursos Naturais). Essa idéia, que potencialmente traria benefícios reais em direção ao aumento da funcionabilidade ecológica das TIs, depende para a sua realização do envolvimento de profissionais que saibam dialogar com saberes de diversas áreas do conhecimento e operacionalizá-los em propostas coerentes.

Finalmente, o livro traz reflexões e informações significativas sobre a problemática da sobreposição entre TIs e UCs, contribuindo também para a compreensão de outros desafios socioambientais multiétnicos da atualidade. Com essa publicação o ISA abriu a porta para uma discussão importante, quiçá para soluções verdadeiramente operacionalizáveis. Falta agora saber se teremos a coragem de passar por ela.

ANA Beatriz Miragliaé mestranda em Antropologia Social no Programa de Pós Graduação do Departamento de Antropologia Social da Universidade de São Paulo. Rui Sérgio Murrieta é Professor do Departamento de Genética e Biologia Evolutiva da USP. 